
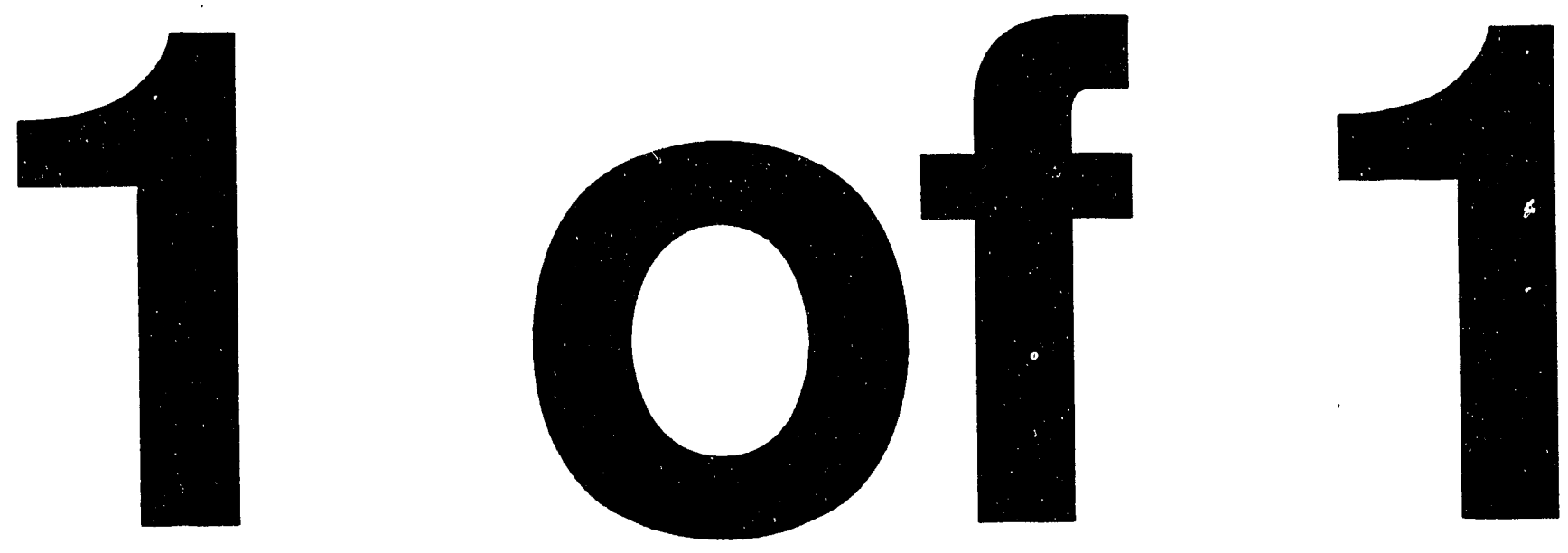


\title{
Public and Institutional Environmental Education \\ In The 1990s
}

\author{
Stuart V. Price \\ Westinghouse Electric Corporation \\ Carlsbad, New Mexico 88221 \\ $505-887-8638$ \\ Paul R. Johnson \\ Westinghouse Electric Corporation \\ Carlsbad, New Mexico 88221 \\ $505-887-8123$
}

Thirty years ago, only a few far-sighted parties were concerned with environmental protection. Today, our nation is witnessing an unprecedented mandate for proper environmental management. Along with this mandate comes the need for public and institutional environmental education. Today, the Waste Isolation Pilot Plant (WIPP) shows us how these education demands have, and have not, been met.

Public environmental education at the WIPP means communicating general project information. For example, the WIPP is a Department of Energy (DOE) nuclear waste disposal research and development (R\&D) facility. Located in the state of New Mexico, the WIPP is managed and operated for the DOE by Westinghouse Electric Corporation (WEC). The WIPP repository, located 2150 feet below ground in geologic salt beds, is designed to be the nation's first permanent disposal site for radioactive transuranic (TRU) wastes generated at U.S. nuclear weapons plants. Throughout WIPP's 15-year history, news media, state libraries, professional seminars, and WIPP information centers have served as public communication avenues. Both the DOE and the WEC have also staffed general information departments and conducted site tours for the public. Despite these attempts to explain project facts, though, misinformation and rumors about the WIPP project still take place. For instance, many sources have incorrectly reported underground roof falls at WIPP, the nature of the waste WIPP will handle, and the contents of certain agreements between the DOE, the U.S. Environmental Protection Agency (EPA), and the state of New Mexico. This type of misinformation has caused some citizens to form opinions of the project not based on fact.

Institutional environmental education typically involves conducting training programs within an organization. In Fall 1990, WEC and the DOE initiated a broad institutional environmental training program by conducting the first School for Environmental Excellence (SEE). This SEE, an eight-week training program based at the DOE site in Ohio, comprised WEC personnel employed at six major DOE nuclear sites, including the WIPP. The training involved three phases. First, students reviewed environmental regulations, litigation, and pollution abatement technologies.

Work supported by the U.S. Department of Energy under DOE Contract No. DE-ACO4-86AL31950

DOE/WIPP $91-062 C$ 
Second, the classes toured the local DOE site to witness ongoing environmental management operations. Third, the students evaluated a hypothetical DOE site with serious environmental concerns. Students developed appropriate responses to regulation questions as part of the final SEE exam. Following this quality prototype school, WEC and the DOE transplanted the program to other DOE sites and invited government and public interest parties to attend. By sitting down and talking with one another in this joint forum, public interest, government regulators, DOE, and private parties can better understand how each other works. Most importantly, environmental management facts can be exchanged and rumors discounted.

To address environmental situations in the 1990s, we need to more effectively join public and institutional education. Inviting concerned citizens to attend the WEC/DOE SEE is a start. By joining industrial and public awareness concerns, industrial/environmental misunderstandings can be corrected and appropriate solutions to all concerns achieved.

02111

\section{DISCLAIMER}

This report was prepared as an account of work sponsored by an agency of the United States Government. Neither the United States Government nor any agency thereof, nor any of their employees, makes any warranty, express or implied, or assumes any legal liability or responsibility for the accuracy, completeness, or usefulness of any information, apparatus, product, or process disclosed, or represents that its use would not infringe privately owned rights. Reference herein to any specific commercial product, process, or service by trade name, trademark, manufacturer, or otherwise does not necessarily constitute or imply its endorsement, recommendation, or favoring by the United States Government or any agency thereof. The views and opinions of authors expressed herein do not necessarily state or reflect those of the United States Government or any agency thereof. 

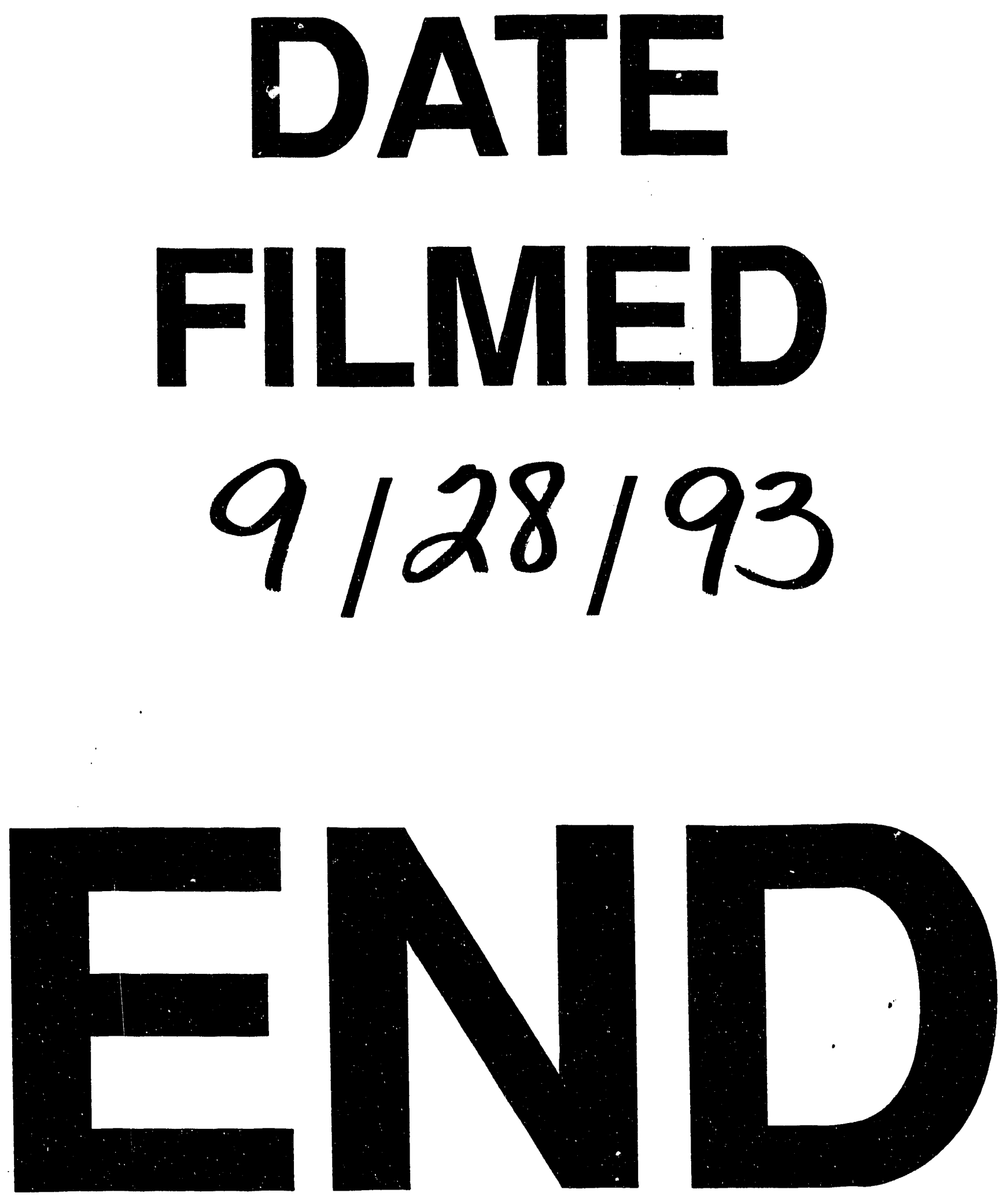
